\title{
Numerical Comparative Study on the Effective Replacement Thickness of Traditional Stone Coarse Aggregate or Steel-Slag Aggregate Mixtures in Improved Soft Fine Soils
}

\author{
Naema Ali Ali \\ Faculty of Engineering, Pharos University in Alexandria, Alexandria, Egypt \\ Email: Dr_Naemaali1@yahoo.com
}

How to cite this paper: Ali, N.A. (2022) Numerical Comparative Study on the Effective Replacement Thickness of Traditional Stone Course Coarse Aggregate or Steel-Slag Aggregate Mixtures in Improved Soft Fine Soils. Journal of Surface Engineered Materials and Advanced Technology, 12, 23-33.

https://doi.org/10.4236/jsemat.2022.122003

Received: January 9, 2022

Accepted: February 22, 2022

Published: February 25, 2022

Copyright $\odot 2022$ by author(s) and Scientific Research Publishing Inc. This work is licensed under the Creative Commons Attribution International License (CC BY 4.0).

http://creativecommons.org/licenses/by/4.0/

(c) (i) Open Access

\begin{abstract}
This study uses Steel Slag Coarse Aggregate (SSCA) as a mixture replacement, preamble material to improve soft soils, which is economic, and has good effect environment. Recently, the development and utilization of by-product, waste and recycle materials must be studied and investigated as a source of improved material for soft soils as, an economic and good effect environmental. The study analyzes effects of both replaced mixtures, (SSCA) or (TSCA) on improved soil bearing capacity and expected settlement after verifying the model. Numerical modeling of the one of real store loaded strip using, PLAXIS, 2D, strain deformation behavior to achieve field visible and measured deformations of untreated soft soil. Numerical studies were devolved to investigate geomechanics parameters improved to compare between using (SSCA) or (TSCA) as, replacement mixture. Results demonstrate that using (SSCA) improved compressibility and strength of shallow soft soil layer significantly than using (TCSA) mixture, while (SSCA) improved strip footing ultimate bearing capacity, (UBC), by $84.4 \%$ compared with increase of $20.5 \%$ when using (TCSA) mixture at the same thickness. In addition, the study highlights the effective (SSCA) replacement thickness ranges between $(0.65 \sim$ 0.80 ) footing width.
\end{abstract}

\section{Keywords}

Steel Slag, Coarse Aggregate, Soft Soil, Improvement, Finite Elements Method, Stress-Strain Behavior

\section{Introduction}

A comparative numerical study of the optimum thickness of the mixtures of re- 
placement layer (SSCA) or Traditional Stone Coarse Aggregate (TSCA) mixed with dry natural soil is investigated. Many studies had investigated and reported that the by-product of the steel industry has many advantages to use in construction road and other engineering concrete work as aggregate in wildly grain sizes. In addition, steel slag has been widely used in many civil engineer applications and construction and recommended, as the fiber used as a source of aggregates for many civil engineering constructions [1] [2] [3].

The primary purpose of sustainability improved the shallow soft soils deposit by using practical engineering partial replacement, to reduce excessive settlement when subjected to excess load, by increasing its low bearing capacity and controlling its deformations. Using Steel Slag Coarse Aggregate (SSCA) mixed with dry weight of this soil as replacement mixture used to improve soft soils in Egypt is economic and has a good effect on environment. Recently it should develop utilization such as waste and recycle materials as a source of improved material for problematic/soft soils.

Using replacement of soft fine soils by coarse material was investigated in many studies as, surface drainage or vertical drains to accelerate the soil settlement and improve its properties before construction on it [1] [3] [4] [5].

The saturated soft fine soil is one of the problems soil needs to improve before being constructed on it. Many researchers had recorded many different methods for improved problem soil, lowering ground-water, pile stone, and replacement with different granular. Also, lightweight expanded clay aggregates have been developed as approaches of improved soft fine soil parameters for engineering studies [3] [4] [6] [7].

Also, when compared between many methods of mitigating fine soft soils, geo-technical properties, the partial replacement of any shallow depth of these soft fine soils, in practical engineering work, improvement can be an effective method.

There are many methods used to mitigate soft fine soils foundation layer, under applied foundation load affecting, such as improved method by injection stabilization and solidification [2] [6] [7] [8].

In this study based on numerical fundamental stress strain model values [9] [10] [11] [12], this study investigate geotechnical parameters mitigating fine soft soils were compared to carry out an effective thickness of different replacement materials used. Therefore, many parametric numerically study to achieve and focused on the mechanical performance of soil treated systems. As quoted by reference [13], "However, until now the practical thickness of replacement is usually selected based on soil experts' experience".

Thus, a series of numerical models suggested study loaded strip support on the different thickness and different materials of replacement to carry out and record the mechanical behavior during the analyses to optimize replacement thickness model. The strip footing loaded model study considers stress-strain performance. In addition, one model of untreated soil was simulated the true store strip loaded 
area observed and recorded in the site to realize site deformation and failure capacity of natural soil. In addition, the bearing capacity of the improved soil cases by different replacement (SSCA) or (TCSA) mixtures thickness have been investigated and calculated to conclude the results of this comparative study.

The effective thickness of partially replacement mixtures (SSCA) or (TCSA) that may be found under loaded rigid strip is predicted from a numerical model for loaded strip store area establish using finite element analysis. The effects of different parameters in improved saturated fine soft soil to increase its load capacity and reduce its total and differential settlements have been studied and compared. Also, natural untreated saturated fine soft soil and loaded strip area are simulated on a numerical model for comparison with deformation measured and recorded in the site under surcharge store loading. The numerical analysis is carried out using the well-known software package PLAXIS 2D, version 8.6.

\section{Zone Considered and Observed Soil Acting Field}

The paper presents suggested improved part of soft soil in the site of salt stores at Al-Qubari-reconstruction axis, Alexandria, under store load, as a numerical case study. "Soil in site stratified, top layer with depth $2.0 \mathrm{~m}$ is silty sandy clay filling, rest on silty clay layer with depth eleven meter overhead of fine sand soil extended to depth twenty-five meter. The water table depth was noted at a depth of $1.50 \mathrm{~m}$ from the ground surface. Field and laboratory investigations were carried out to determine soil properties".

Investigate the effective and optimum thickness of different replacement material layers of natural graded granular soil, (TCSA) or slag coarse aggregate, (SSCA) with numerically study. After investigating the soil characteristics from a realistic case study which are simulated numerically to achieve actual soil parameters that were deduced from laboratory tests on soil samples which were extracted from the site, as well as the field testes results that were executed during samples taking out. The numerical study was carried out by many numerical models using PLAXIS 2D to represent the natural soil layers which loaded with the storage load to achieve the actual subsidence and loading capacity of the soil as was monitored in the site to verify the indications soil parameters used in the numerical analysis to study the optimum replacement thickness.

The verified numerical soil model has been used in this study to investigate the efficiency of the remove and replace method for improvement of the saturated soft fine soil considering different replacement materials, (SSCA) and (TCSA) to inspect optimum thickness, interaction area, stiffness, and density.

The natural soft fine soil and the replacement material, effective properties resulting from experimental tests conducted in the lab and needed in this numerical study to simulate the actual performance of actual and improved soil model are illustrated in Table 1. The numerical model of strain deformation behavior of the shallow soft soil layer is investigated and compared using (SSCA) and (TCSA) as a top partial replacement drainage material. 
Table 1. Replacement mixture, thickness, and its properties used in the numerical study.

\begin{tabular}{cccc}
\hline Properties & $\begin{array}{c}\text { Upper Soft } \\
\text { Clay Soil }\end{array}$ & $\begin{array}{c}\text { intersection } \\
\text { soil \& (TCSA) }\end{array}$ & $\begin{array}{c}\text { intersection } \\
\text { soil \& (SSCA) }\end{array}$ \\
\hline Initial water content $(\%)$ & 54.50 & 38.5 & 34.3 \\
Bulk Density $\gamma_{b}\left(\mathrm{kN} / \mathrm{m}^{3}\right)$ & 15.6 & 1.96 & 2.08 \\
Saturated Density $\gamma_{\text {sat }}\left(\mathrm{kN} / \mathrm{m}^{3}\right)$ & 16.672 & 2.00 & 2.12 \\
Layer thickness & $5 \mathrm{~B}$ & $0.10 \mathrm{~B}$ & $0.25 \mathrm{~B}$ \\
Shear Strength, lab vane, Su (kPa) & 20 & 100 & 120 \\
\hline
\end{tabular}

$B$, is Loaded area width, (footing width).

\section{Numerical Model}

The numerical analysis of the natural state was carried out with 2D finite-element software PLAXIS 2D, version 8.6. The result of the experimental modal foundation system was considered natural soft soil case and the soil improved with replacement mixture, (SSCA) or (TCSA) with percentage $50 \%$ and its varies replacement thickness, $(\mathrm{H} / \mathrm{B})=(0.5,0.65,1.0,1.5)$ in numerical analysis with strip footing with width $7500 \mathrm{~mm}$, (presented the field loaded strip considered) rested on two cases of replacement. The two cases simulated the obtained reference settlement and ultimate bearing capacity of this strip footing soil arrangement system. Also, the intersection soil presented the bottom interlocking between the top of natural soil with a mixture of replacement material as in Lab experimental tests. Two soil models have been used in the finite element analysis, the hardening soil model, (HS) and the soft soil model, (SS) to consider the increase of soil stiffness. The replacement mixture, (SSCA) or (TCSA) layer is modeled as an elastic-plastic model depending on the Mohr-Coulomb failure criterion in PLAXIS. Table 2 contains the soil parameters used in two models consider in this study. After preliminary simulations, Figure 1 shows the dimension, lateral boundaries condition, and scale factor of the numerical model analysis system considered. The developed finite element mesh, in this, studied for arrangement model for two improved mixtures replacements results are compared.

In the case of natural soil, several trials to catch enough foundation vertical load steps development and achieve ultimate state, Qu reached and corresponding its settlement have inspected from the output of analyses and load-displacement curve for each load step. At ultimately failed load measured and its related vertical field deformation was inspected to examine and justify the numerical analysis results, as shown in Figure 2. The top filling layer in the field has been simulated as a surcharge surface load and considered its settlement. Figure 2 indicates a good comparison between the predicted settlement from the model study and measured observed vertical settlement to realize the assumption and soil data in the numerical model considered in this study.

After verification of numerical models and soil parameters, the study cases of various replacement thicknesses, $(\mathrm{H} / \mathrm{B})=(0.5,0.65,1.0,1.5)$ were investigated to 
Table 2. Natural soil and replacement mixture, properties used in two model finite element analysis.

\begin{tabular}{|c|c|c|c|c|c|c|}
\hline Properties & $\begin{array}{l}\text { Upper Soft } \\
\text { Clay Soil }\end{array}$ & $\begin{array}{l}\text { Lower Clay } \\
\text { Soil }\end{array}$ & $\begin{array}{l}\text { intersection } \\
\text { soil \& (TCSA) }\end{array}$ & $\begin{array}{c}\text { Replacement } \\
\text { mixture (TCSA) }\end{array}$ & $\begin{array}{l}\text { intersection soil } \\
\& \text { (SSCA) }\end{array}$ & $\begin{array}{l}\text { Replacement } \\
\text { mixture (SSCA) }\end{array}$ \\
\hline Model & SS/HS & SS/HS & MC & MC & MC & MC \\
\hline Drainage & Undrained & Undrained & drained & drained & drained & drained \\
\hline$\gamma_{b}\left(\mathrm{kN} / \mathrm{m}^{3}\right)$ & 15.60 & 18.40 & 1.96 & 20.08 & 2.08 & 2.24 \\
\hline$\gamma_{\text {sat. }}\left(\mathrm{kN} / \mathrm{m}^{3}\right)$ & 16.67 & 19.36 & 20.00 & 21.02 & 21.20 & 2.38 \\
\hline$c_{k}$ & 20 & 58 & 60 & 50 & 60 & 50 \\
\hline$c_{r e f}^{\prime}\left(\mathrm{kN} / \mathrm{m}^{2}\right)$ & 1 & 1 & 1 & 1 & 1 & 1 \\
\hline$\phi^{\prime}\left({ }^{\circ}\right)$ & 25 & 30 & 35 & 35 & 35 & 40 \\
\hline$\psi^{\prime}\left({ }^{\circ}\right)$ & 0 & 0 & 0 & 0 & 0 & 0 \\
\hline$e_{o}$ & 1.428 & 0.88 & 0.7 & 0.5 & 0.6 & 0.5 \\
\hline$\lambda^{*}$ & 0.095 & 0.077 & - & - & - & - \\
\hline$k^{*}$ & 0.025 & 0.075 & - & - & - & - \\
\hline OCR & 1.30 & 2.56 & - & - & - & - \\
\hline$E_{50}(\mathrm{Mpa})$ & 1.20 & 2.20 & - & - & - & - \\
\hline$E_{o e d}(\mathrm{Mpa})$ & 1.04 & 1.02 & - & - & - & - \\
\hline$E_{u r}(\mathrm{Mpa})$ & 5.80 & 3.62 & - & - & - & - \\
\hline$E^{\prime}(\mathrm{Mpa})$ & - & - & 30.0 & 35.0 & 32.0 & 50.0 \\
\hline$E_{\text {oed }}(\mathrm{Mpa})$ & - & - & 35.0 & 45.0 & 42.0 & 65.0 \\
\hline$v^{\prime}$ & - & - & 0.25 & 0.25 & 0.25 & 0.25 \\
\hline
\end{tabular}
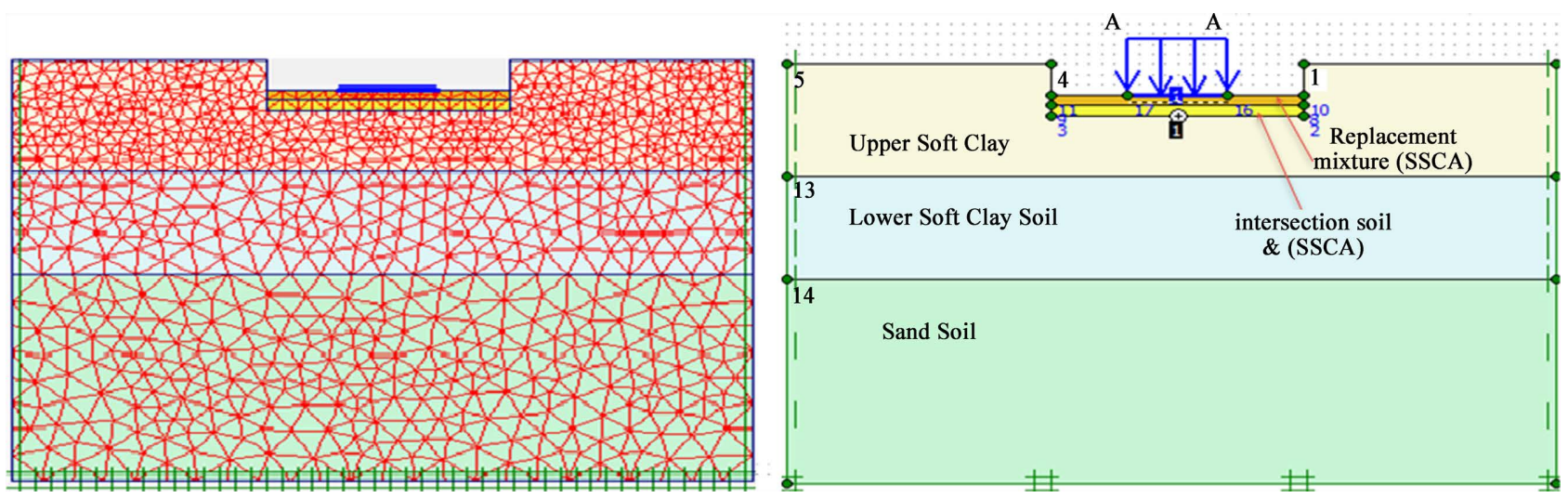

Figure 1. Finite element mesh and strip footing soil arrangement system.

reach the optimum replacement thickness, $(\mathrm{H} / \mathrm{B})$ as in lab experimental tests.

Figure 3 \& Figure 4 illustrate the comparative results of three cases studied of replacement thickness with the case without any replacement for two replacement material mixture, (SSCA) and (TCSA) studied. The figures indicated that the replacement mixture, (SSCA) is more effective in improving fine soil and reduced the strip vertical settlement by about $49.5 \%$ with an effective thickness 


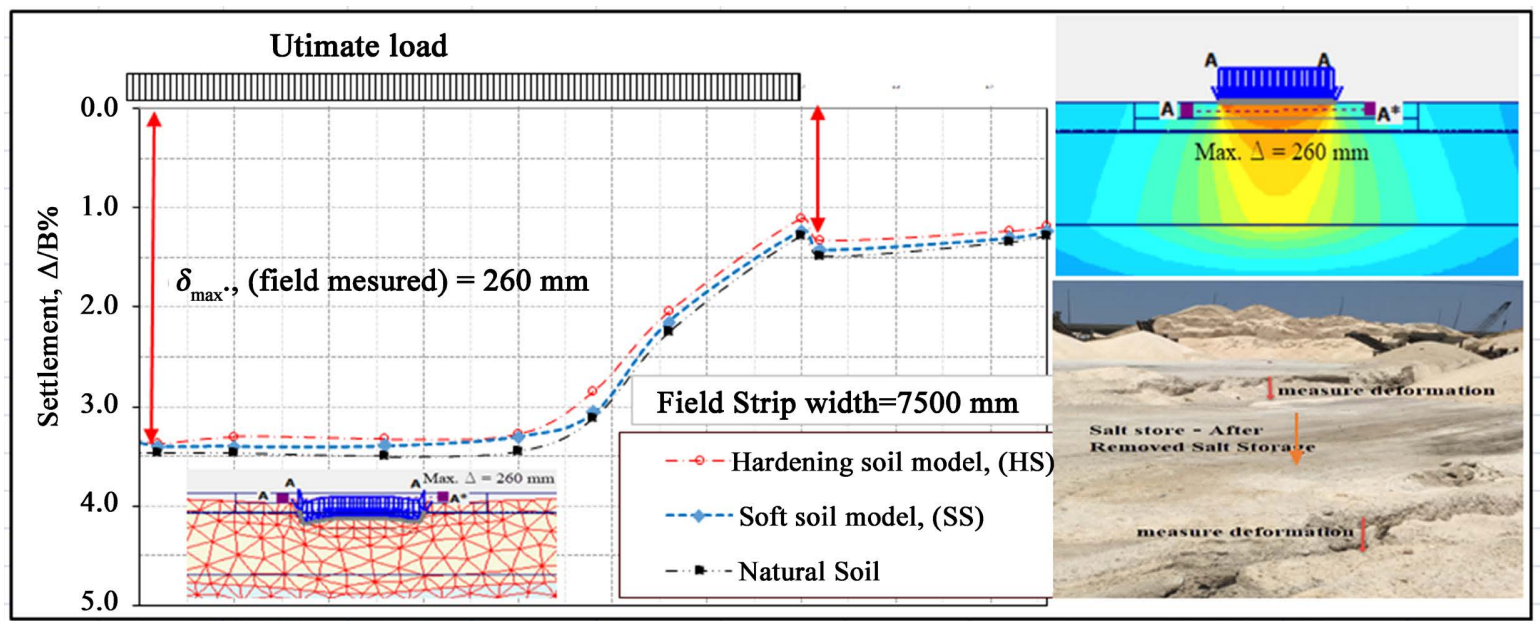

Figure 2. Foundation of normalized vertical displacement at failure load step, justified with field measured, considering two soil modes, (HS) and (SS).

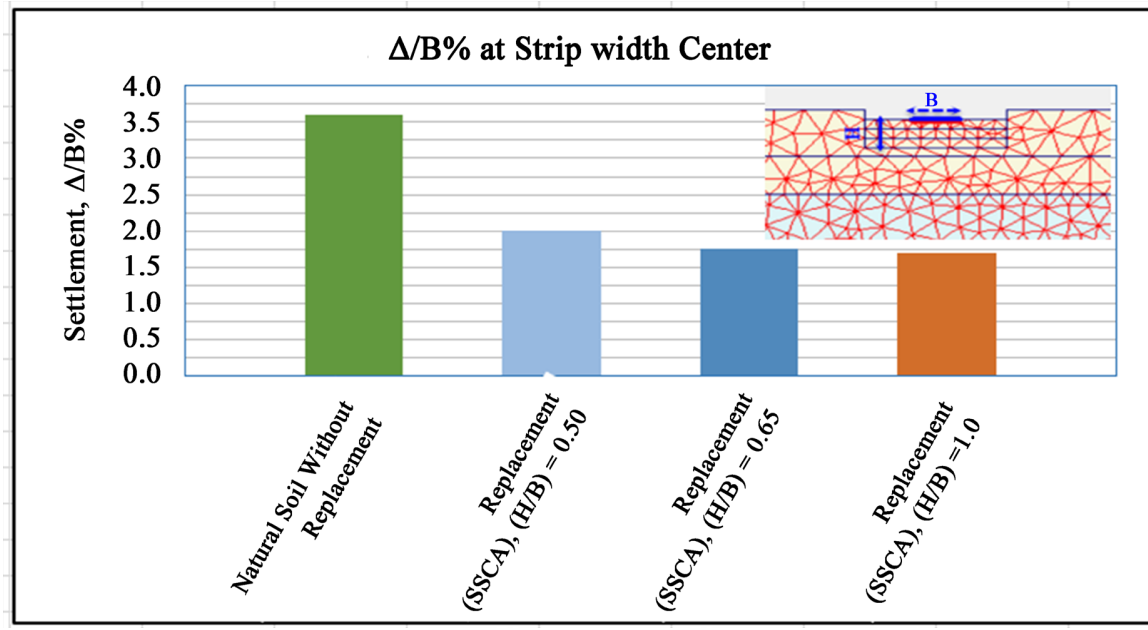

Figure 3. A comparative normalized vertical displacement, replacement mixture, (SSCA).

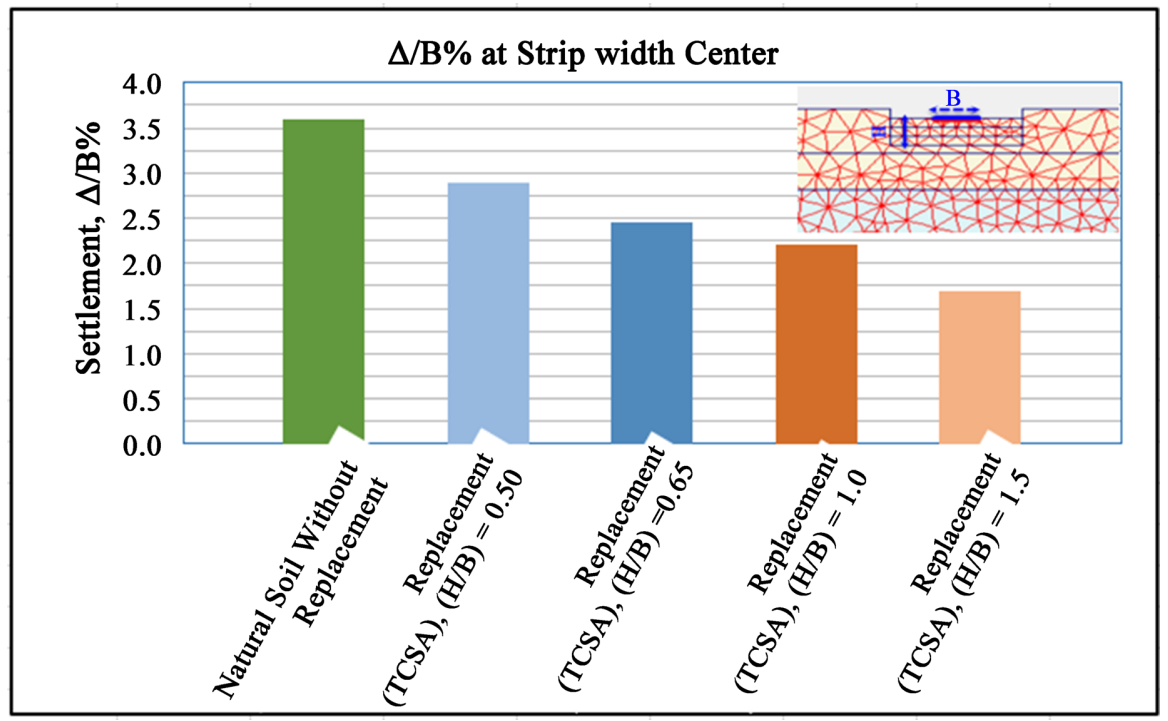

Figure 4. A comparative normalized vertical displacement, replacement mixture, (TCSA). 
of (SSCA) not exceeding 0.65 the width of a strip foundation, $(\mathrm{H} / \mathrm{B}=0.65)$. While using (TCSA) reduced the vertical settlement of the same strip footing by about $28.4 \%$ with a larger effective thickness of (TCSA), $(\mathrm{H} / \mathrm{B}=1.50)$.

Numerical analyses, results as, pressure-settlement curves for natural soil and improved soil by two replacement material mixtures, (SSCA) and (TCSA) studied, illustrate in Figure 5. From pressure settlement curves the ultimate bearing capacity can be determined by the tangent intersection method. Comparative between these values of ultimate bearing capacity indicates that using replacement material mixture, (SSCA) with $\mathrm{H} / \mathrm{B}=0.65$ improved strip footing ultimate bearing capacity by $84.4 \%$, while using replacement material mixture, (TCSA) with $\mathrm{H} / \mathrm{B}=1.5$, improved strip footing ultimate bearing capacity by $55.6 \%$.

Many results can be appreciated from numerical analyses to more incentive the performance of cases studied. Figures 6-8 show some results of the analyses as, the deformed mesh, vertical displacement, vertical stress, vertical strain, and excess pore water pressure reduction under strip foundation, at ultimate load step of using replacement mixture of (SSCA), is improved. Also, the analysis can be used to highlight a reduction in long-term deformation problems in the shallow soft soil layer, by using back analysis considering the soft creep model for the same arrangement of strip footing replacement soft soil layers' model.

The comparison between strip footing vertical displacement rest in improved layer with thickness $0.65 \mathrm{~m}$ using (SSCA) and (TCSA) mixtures are shown in Figure 9. Many cases have been studied in this model for the best and optimum

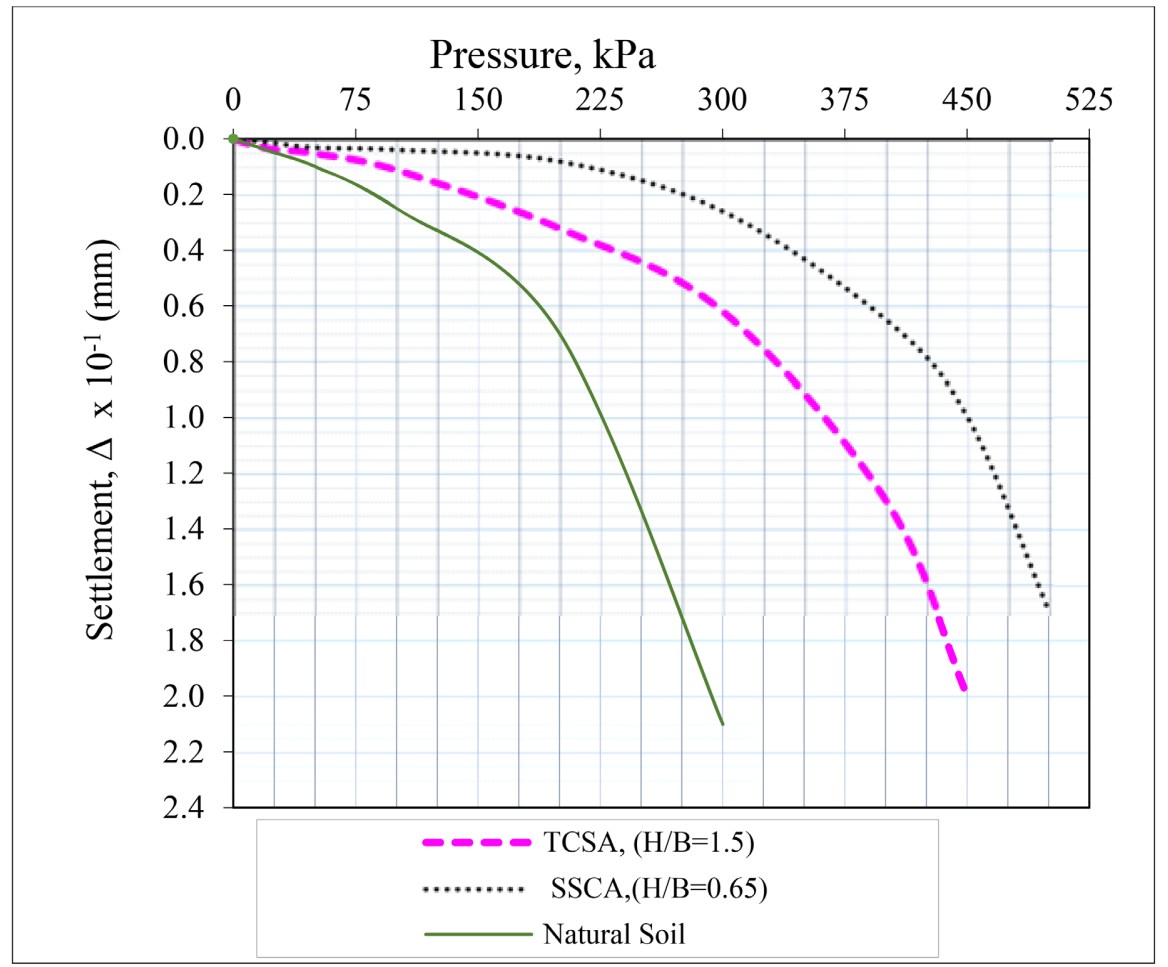

Figure 5. A comparative pressure-settlement curves for case study. 


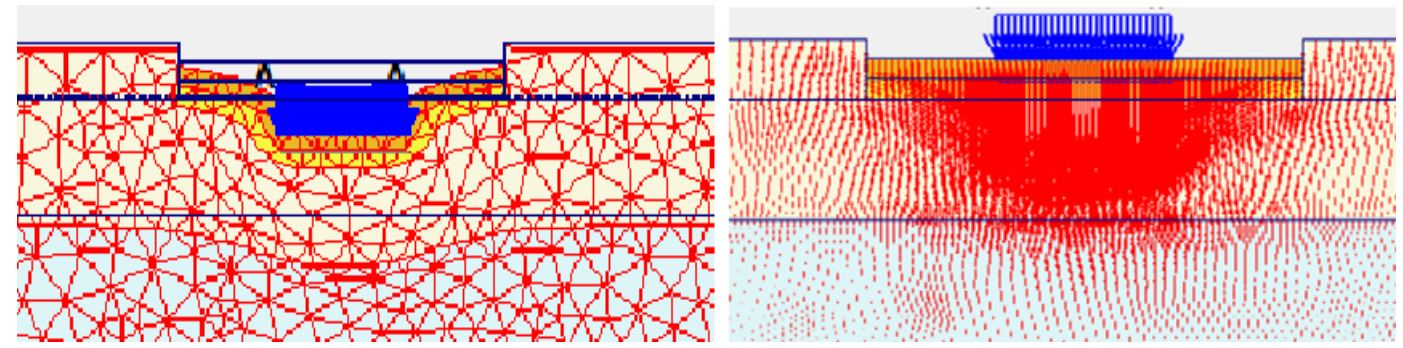

Figure 6. Foundation of deformed mesh and vertical displacement at ultimate load step.
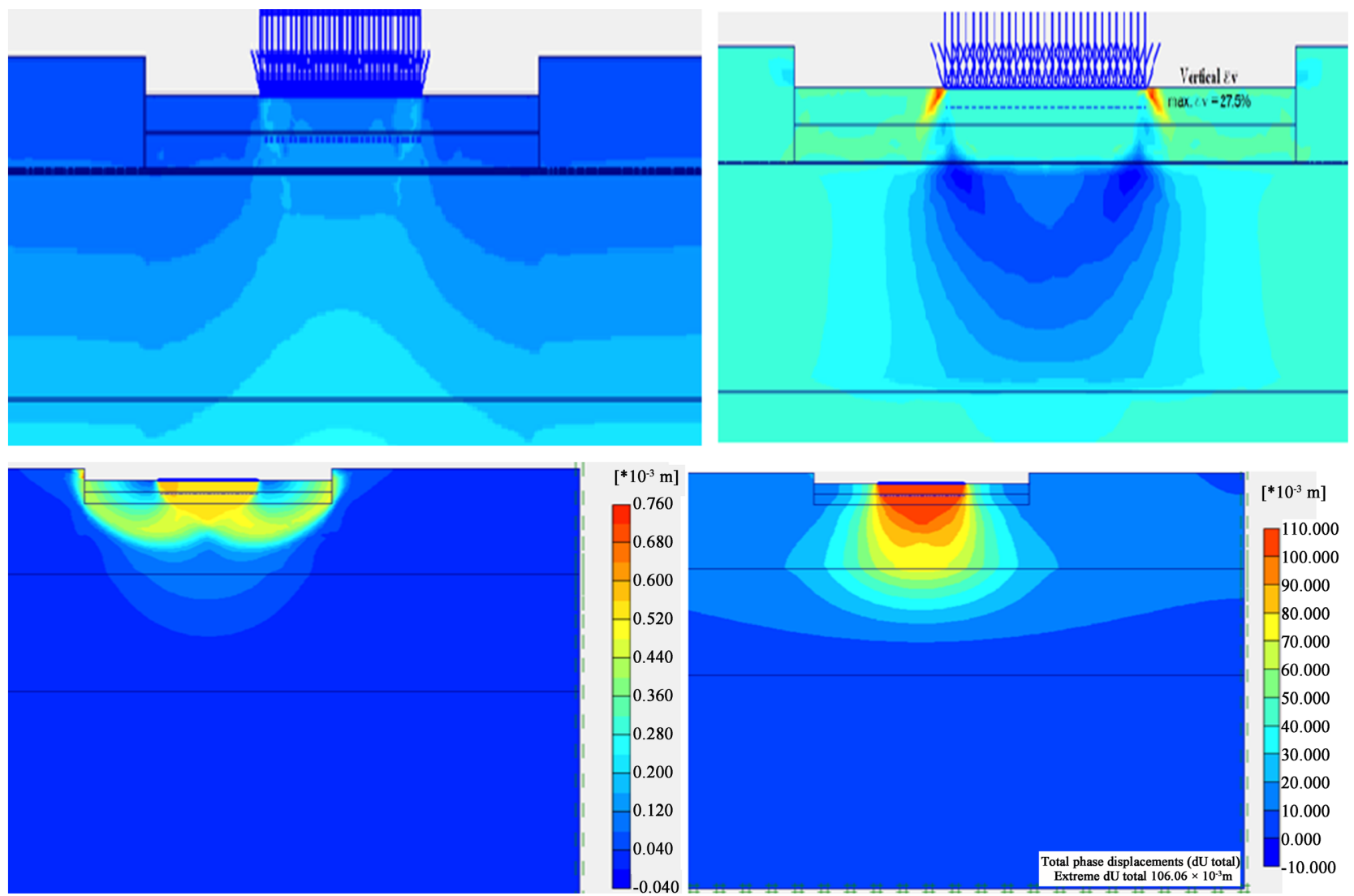

Figure 7. Foundation of vertical stress and vertical strain at ultimate load step.

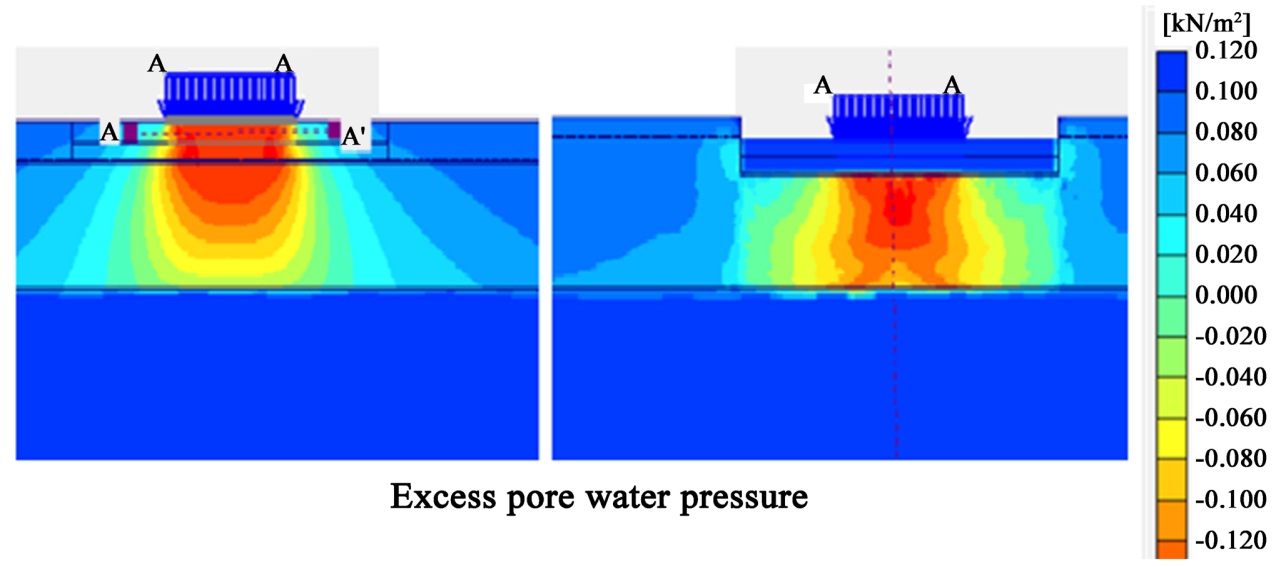

Figure 8. Excess pore water pressure under strip foundation. 


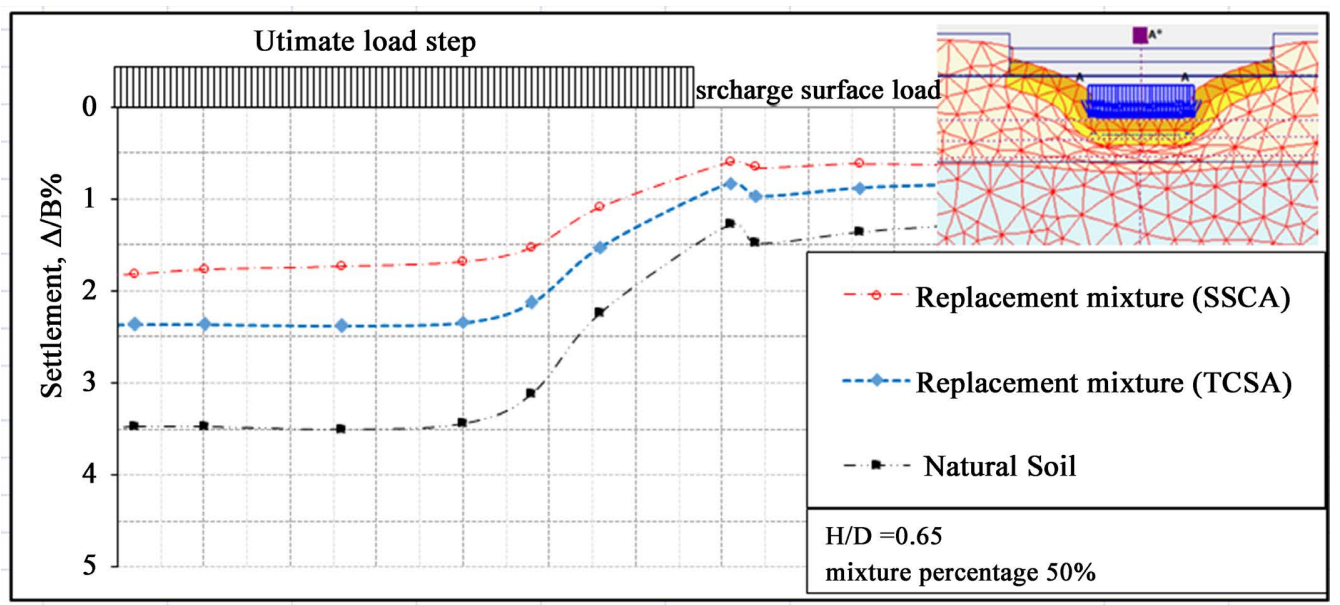

Figure 9. A comparative normalized vertical displacement performance of treated soil.

replacement thickness under foundation, as shown in figures. The results indicate that the identical conclusion expected by lab experimental study in another work of others.

Figure 9 illustrates the surcharge acting on the surface of natural soft soil by replacement mixture percentage with constant $(\mathrm{H} / \mathrm{D}=0.65)$ and its weight increase preloading to improved excess primary settlement.

In addition, the effective thickness of partially replacement mixtures (SSCA) and (TCSA) has been investigated in case study considering a retail three strips laded areas observed failed in the site and their settlement and deformed shape measured and recorded. Figure 10 represents the effect of two replacement mixtures (SSCA) and (TCSA). The figure indicates that replacement mixtures (SSCA) are more affected in improved soft fine soil with smallest thickness than replacement mixtures (TCSA). Compared using (SSCA) mixture as a replacement at the same thickness result indicate that good improvement achieves than as using (TCSA) mixture as a replacement.

\section{Conclusions}

Recently adapted mathematical modeling analyses to guess and examine the variation of soil foundation system response reverence to plan strain analyses are the admirable trick for satisfactory analyses for geotechnical problems.

Numerical study indicates a good comparison between the predicted settlement and ultimate bearing capacity for strip footing from model study and measured observed vertical settlement with achieving the assumption and soil data in the numerical model considered in this study.

From numerical analysis results, it can be observed the ability of improved soft fine soil by replacement with (SSCA) mixture by increasing the bearing capacity by $184.4 \%$ and reduced settlement by $49.5 \%$ decreases of strip footing rest on this soil and the effective degree of improvement is achieved at thickness equal to 0.65 of strip footing width $(\mathrm{H} / \mathrm{B}=0.65)$. Comparing using (TCSA) mixture as a replacement at the same thickness result indicated that the same improvement 


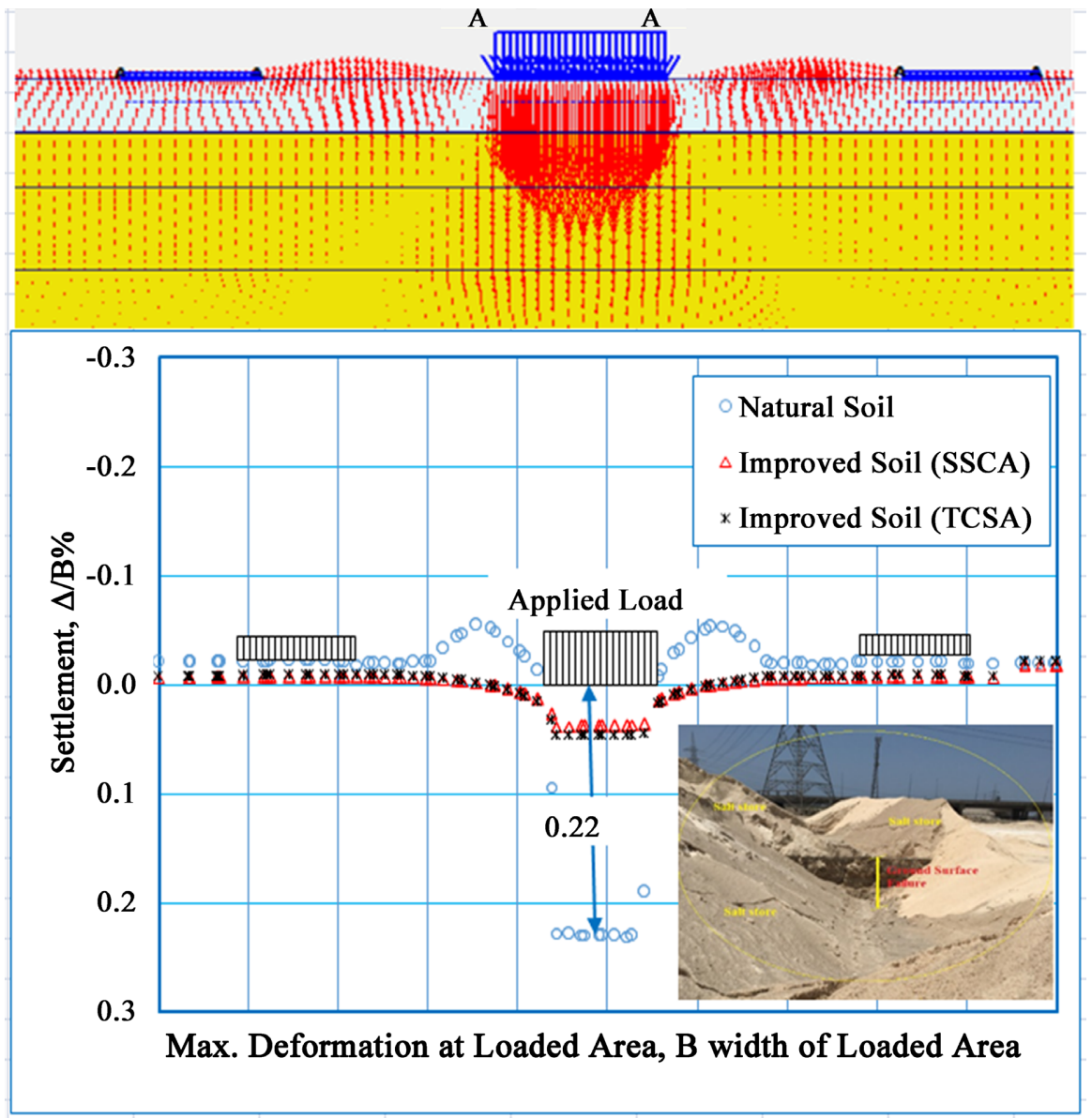

Figure 10. A comparative normalized vertical displacement performance of natural and treated soil.

did not achieve as using (SSCA) as a replacement. But to achieve improved bearing capacity by $154.6 \%$ increases and reduced settlement by $28.4 \%$ decreases of strip footing width, it must use (TCSA) mixture as a replacement thickness not less than, $\mathrm{H} / \mathrm{B}=1.5$.

It was found that the (SSCA) mixture used as a replacement material mixture is more effective in improving the performance of fine soil by its rough surface texture which ensured strong bonding and adhesion than using (TCSA) mixture one at the same thickness.

Also, numerical analyses results can be useful to draw the good regeneration of soil improvement performance and its characteristics and also, can be highlighted on a reduction in soil long-term deformation problems.

\section{Conflicts of Interest}

The author declares no conflicts of interest regarding the publication of this paper.

\section{References}

[1] Rao, A.S. and Sridevi, G. (2011) Utilization of Industrial Wastes in Pavements Laid 
over Expansive Clay Sub-Grades. Proceedings of the Advances in Geotechnical Engineering (Geo-Frontiers'11), Dallas, Tex, March 2011, 4418-4427. https://doi.org/10.1061/41165(397)452

[2] Koteswara Rao, D., et al. (2012) A Laboratory Study on the Effect of Rice Husk Ash and Potassium Chloride for the Stabilization of Expansive Soil. IJEST, 4.

[3] Biggs, J.W. and Mahony, K.M. (2004) Is Soil Science Relevant to Road Infrastructure? Proceedings of the 13 th International Soil Conservation Organization Conference (ISCO'04), Brisbane, Australia, Paper No. 410.

[4] Azhani Zukr, A., Ramli Nazir, B. and Ng Kok Shien, C. (2018) The Settlement Evaluation of Improved Soft Clay Using LECA Replacement Technique. Proceeding 20th SEAGC-3rd AGSSEA Conference in Conjunction with 22nd Annual Indonesian National Conference on Geotechnical Engineering. Jakarta, Indonesia, 6-7 November 2018, 392-397.

[5] Shoaei, M.D., Alkarni, A., Noorzaei, J., Jaafar, M.S. and Huat, B.B.K. (2012) Review of Available Approaches for Ultimate Bearing Capacity of Two-Layered Soils. Journal of Civil Engineering and Management, 18, 469-482.

https://doi.org/10.3846/13923730.2012.699930

[6] Lijun, H., Li, J.S., Xue, Q. and Chen, Z. (2020) Bacterial-Induced Mineralization (BIM) for Soil Solidification and Heavy Metal Stabilization: A Critical Review. Journal of Science of the Total Environment, 746, Article ID: 140967.

https://www.elsevier.com/locate/scitotenv https://doi.org/10.1016/j.scitotenv.2020.140967

[7] Wang, Z.Y., Zhang, N., Cai, G.J., Jin, Y., Ding, N. and Shen, D.J. (2017) Review of Ground Improvement Using Microbial Induced Carbonate Precipitation (MICP). Marine Georesources \& Geotechnology, 35, 1135-1146. https://doi.org/10.1080/1064119X.2017.1297877

[8] Turkoz, M. and Vural, P. (2013) The Effects of Cement and Natural Zeolite Additives on Problematic Clay Soils. Science and Engineering of Composite Materials, 20, 395-405. https://doi.org/10.1515/secm-2012-0104

[9] Isakov, A. and Moryachkov, Y. (2014) Estimation of Slope Stability Using Two-Parameter Criterion of Stability. International Journal of Geomechanics, 14, Article ID: 06014004. https://doi.org/10.1061/(ASCE)GM.1943-5622.0000326

[10] Ahmad, J., Noo, M.J.M., Jais, I.B.M., et al. (2018) Mathematical Models for Stress-Strain Curve Prediction-A Review. AIP Conference Proceedings, 2020, Article ID: 020005. https://doi.org/10.1063/1.5062631

[11] Jiki, P.N., Agber, J.U. and Osadebe, N.N. (2012) Finite Element Evaluation of Bearing Capacity Parameters for Soils in the University of Agriculture, Makurdi. Indian Journal of Innovations and Developments, 1, 121-126.

[12] El-Kady, M.S., Essam, F., Wassef, O. and Muhammad, T.B. (2021) Finite Element Slope Stability Analysis by Geofoam Technique. International Journal of Scientific \& Technology, 10, 244-248.

[13] Abd Elhamid, M., Abdelaziz, T. and Bassioni, H. (2021) Factors Affecting the Thickness of Replacement Layer on Medium Clay. ASEAN Engineering Journal, 11, 234. https://doi.org/10.11113/aej.v11.18035 